\title{
Effectiveness of an accounting videogame in terms of attributes, motivation and learning outcomes
}

\author{
Jordi Carenys \\ EADA Business School \\ jcarenys@eada.edu \\ Soledad Moya \\ ESADE Business School. Universitat Ramon Llull \\ soledad.moya@esade.edu \\ Mar Vila \\ ESADE Business School. Universitat Ramon Llull \\ mar.vila@esade.edu
}

\begin{abstract}
The objective of this study is to assess the effectiveness of an accounting videogame with regard to attributes, motivation, and learning outcomes. Results show that, regarding attributes, most of them were favourably assessed, being the most valued those related to fun, engagement and the provision of clear information about the goals while the less valued were those regarding feedback. For motivation, results show that also participants perceive the learning experience as motivating, with a particular focus on enjoyment and sense of success. And regarding learning outcomes, results show the highest values meaning that students perceive that they are learning with the experience and achieving their objectives.
\end{abstract}

Keywords: accounting, videogames, attributes, motivation, learning outcomes. 
Un videojuego de contabilidad y su eficacia en cuanto a sus atributos, motivación y resultados de aprendizaje

\section{Resumen}

El objetivo del presente trabajo es valorar la efectividad de un videojuego de contabilidad en relación a sus atributos, motivación y resultados de aprendizaje. Los resultados muestran que, en relación a los atributos, la mayoría fueron evaluados favorablemente, destacando los relacionados con diversión, adicción y la provisión de información clara sobre los objetivos mientras que los menos valorados fueron los relacionados con la retroalimentación. En cuanto a la motivación, los resultados muestran que los estudiantes perciben la actividad como motivadora, sobre todo en cuanto a disfrute con el juego y sensación de éxito. $Y$, en cuanto a los objetivos de aprendizaje, los resultados dan sus valores más altos demostrando que los participantes perciben que aprenden y que consiguen sus objetivos.

Palabras clave: contabilidad, videojuegos, atributos, motivación, resultados de aprendizaje. 


\section{Introduction}

Different dimensions have been considered in the literature when assessing the effectiveness of digital games (Bedwell, Pavlas, Heyne, Lazzara, \& Salas, 2012; Calabor, Mora, \& Moya, 2017; Carenys, Moya, \& Perramon, 2016; Garris, Ahlers, \& Driskell, 2002; Huang, Johnson, \& Han, 2013; Wilson et alii, 2009) and some of the more often analysed have been the attributes of the game, the motivation generated and the achievement of learning outcomes (sometimes from an individual perspective and some - Bedwell et alii, 2012; Wilson et alii, 2009 - from a multidimensional one) as they have showed to be the ones that, for the moment, better explain the effectiveness of games in higher education environments.

In the accounting literature, effectiveness studies regarding digital game based learning are still scarce (Carenys \& Moya, 2016) and this seems to be related to the also uncommon use of games in accounting higher education classrooms (Calabor, Moya, \& Mora, 2016). However, prior literature shows that the use of digital games in higher education can promote more effective learning effectiveness (Buckley \& Doyle, 2014; Chen \& Law, 2015; Fitó, Hernández, \& Serradell, 2015; Guillén \& Aleson 2012).

Therefore, the objective of this study is to assess the effectiveness of an accounting videogame with regard to attributes, motivation, and learning outcomes, as three of the main dimensions that play a role in the effectiveness of Digital Game Based Learning (DGBL). To assess our objective, we have conducted an experiment in the second year of a Bachelor in Business Administration (BBA) programme in a Spanish Business School for a sample of 215 students where participants have played individually with the videogame answering afterwards to a questionnaire regarding their perceptions on attributes, motivation and learning outcomes.

The videogame used is a Working Capital game where participants have to deal with the different stages of working capital management in order to maximize the value of the company. The game can be played individually or in groups and offers different levels of achievement.

The results of our paper show that first and regarding attributes, most of them were favourably assessed by participants, being the most valued those related to fun, engagement and the provision of clear information about the goals while the less valued were those regarding feedback. Secondly and for motivation, results show that also participants perceive the learning experience as motivating, with a particular focus on enjoyment and sense of success. Finally, and regarding learning outcomes, results show the highest values meaning that 
students perceive that they are learning with the experience and achieving their objectives. Gender was not significant for any of the dimensions analysed.

Additionally, results show a very weak correlation between liking of the games and the perceptions of attributes, motivation and learning outcomes showing that the use of videogames was able to generate a strong positive effect even for those students not fond of them.

The remainder of this paper is structured as follows: section 2 deals with the literature review and the research questions, section 3 explains the data and methodology, section 4 presents our results and, finally, in section 5 we summarize our conclusions.

\section{Literature review and research questions}

Attributes may be defined (Yusoff, 2010) as the aspects of a game that support learning and engagement and that are based on the exploration of the established theories of learning and motivation'. Attributes are therefore essential variables in any conceptual framework designed for the assessment of effectiveness. Garris et alii (2002) refer in their study to game attributes (often also referred to as 'characteristics' or 'features' in the literature) and their relationship to learning outcomes. The authors present an input-process-output model of instructional games with three main steps. In the first step, the instructional program is designed taking into consideration instructional content and several attributes of the game. In the second step, the attributes promote a cycle that includes behaviour, judgment, and feedback. If these two steps are properly developed and the content is successfully paired with the attributes, the cycle generates recurring and self-motivated game play. In the third step, this engagement in game play leads to the achievement of training objectives and specific learning outcomes. Based on their literature review, the attributes selected are fantasy, rules and goals, sensory stimuli, challenge, mystery, and control.

Wilson et alii (2009) and Bedwell et alii (2012) both similarly attempt to determine the relationship between attributes and learning outcomes. Wilson et alii (2009) select a set of attributes based on a review of the literature. In the former paper, the authors refer to adaptation, assessment, challenge, conflict, control, fantasy, interaction, language communications, location, mystery, pieces or players, progress and surprise, representation, rules and goals, safety, and sensory stimuli. They propose a number of propositions by which different attributes are expected to be related to different learning outcomes. Meanwhile, Bedwell et alii (2012) argue that a list of 16 attributes is not easily manageable and that some attributes may overlap; thus, they propose attribute categories 
based on the card sorts procedure performed by subject matter experts. The final list comprises nine categories, each with associated attributes.

More recently, we find some multidimensional studies that also incorporate attributes (Huang et alii, 2013)2013, basing their selection on previous literature. Therefore, and as for the specific dimension of attributes, we define a list of desired ones that we consider to be relevant for the effectiveness of the learning experience proposed. Our selection is based on the characteristics of our game. Our final list of attributes is provided in Table 1 (Carenys et alii, 2016).

Table 1. Attributes of the simulations (Carenys et alii, 2016)

\begin{tabular}{|c|c|c|}
\hline Attribute & Definition & Sources \\
\hline 1. Challenge & $\begin{array}{l}\text { A challenging activity should be perceived as achievable, } \\
\text { unpredictable, somewhat vague, and designed to stretch } \\
\text { and flex players' existing knowledge or skill levels. The } \\
\text { level of challenge must only minimally exceed learners' } \\
\text { potential competency capacity to overcome the obstacles. } \\
\text { Otherwise, this characteristic might frustrate the learners } \\
\text { in the early stage of play. }\end{array}$ & $\begin{array}{l}\text { (Csikszentmihalyi, 1975), } \\
\text { (Garris et alii, 2002), } \\
\text { (Malone, 1981), (Malone } \\
\text { \& Lepper, 1987), (Rieber } \\
\text { \& Matzko, 2001), (Wilson } \\
\text { et alii, 2009), (Bedwell et } \\
\text { alii, 2012), (Huang et alii, } \\
\text { 2013)2013 }\end{array}$ \\
\hline 2. Competition & $\begin{array}{l}\text { Competition in DGBL can present many forms. } \\
\text { Players may compete with themselves, the game system, } \\
\text { individual players, or other teams to achieve game } \\
\text { objectives. }\end{array}$ & $\begin{array}{l}\text { (Csikszentmihalyi, 1975), } \\
\text { (Amory, 2007), (Moreno- } \\
\text { Ger, Burgos, Sierra, \& } \\
\text { Fernández-Manjón, 2008), } \\
\text { (Rieber \& Noah, 2008), } \\
\text { (Huang et alii, 2013)2013 }\end{array}$ \\
\hline 3. Rules & $\begin{array}{l}\text { Games without rules are meaningless. Rules exemplify } \\
\text { problem-solving processes in various forms for learners } \\
\text { to follow. Game rules further ensure fair play within the } \\
\text { system. }\end{array}$ & $\begin{array}{l}\text { (Garris et alii, 2002), } \\
\text { (Moreno-Ger et alii, } \\
\text { 2008), (Westera, Nadolski, } \\
\text { Hummel, \& Wopereis, } \\
\text { 2008), (Wilson et alii, } \\
\text { 2009), (Bedwell et alii, } \\
\text { 2012), (Calabor, Mora, \& } \\
\text { Moya, 2015) }\end{array}$ \\
\hline $\begin{array}{l}\text { 4. Goal- } \\
\text { oriented tasks }\end{array}$ & $\begin{array}{l}\text { The game includes goal-oriented tasks that can be } \\
\text { defined as building blocks for players to achieve the } \\
\text { winning goal. Incomplete tasks require players to } \\
\text { revisit them until the player's performance meets the } \\
\text { competency requirement. }\end{array}$ & $\begin{array}{l}\text { (Csikszentmihalyi, 1975), } \\
\text { (Malone, 1981), (Bedwell } \\
\text { et alii, 2012), (Huang et alii, } \\
\text { 2013)2013, (Calabor } \text { et alii, } \\
\text { 2015) }\end{array}$ \\
\hline 5. Fantasy & $\begin{array}{l}\text { Games can situate players in a world of fantasy that } \\
\text { is completely detached from reality. Players can have } \\
\text { experiences that are difficult to acquire in the real world } \\
\text { and are constantly engaged in the game playing process. }\end{array}$ & $\begin{array}{l}\text { (Garris et alii, 2002), } \\
\text { (Amory, 2007), (Malone } \\
\text { \& Lepper, 1987), (Wilson } \\
\text { et alii, 2009), (Bedwell et } \\
\text { alii, 2012), (Huang et alii, } \\
\text { 2013)2013 }\end{array}$ \\
\hline
\end{tabular}




\begin{tabular}{|c|c|c|}
\hline Attribute & Definition & Sources \\
\hline $\begin{array}{l}\text { 6. Telling } \\
\text { stories }\end{array}$ & $\begin{array}{l}\text { Games often have distinctive storylines for players to } \\
\text { follow. This is often the case in adventure and historical } \\
\text { games. Storylines add contextual references and } \\
\text { interactional complexity to the game. They help players } \\
\text { to relate their personal experiences and common sense to } \\
\text { the game goals, tasks, and rules. }\end{array}$ & $\begin{array}{l}\text { (Dickey, 2007), (Moreno- } \\
\text { Ger et alii, 2008), (Rieber } \\
\& \text { Noah, 2008), Rieber \& } \\
\text { Matzko, 2001) (Huang et } \\
\text { alii, 2013)2013 }\end{array}$ \\
\hline 7. Engagement & $\begin{array}{l}\text { Engagement enables players to immerse themselves } \\
\text { cognitively and affectively in the game-based } \\
\text { environment. Players consider themselves part of the } \\
\text { game. The experience of 'flow' is the ultimate outcome of } \\
\text { deep engagement in games. }\end{array}$ & $\begin{array}{l}\text { (Csikszentmihalyi, 1975), } \\
\text { (Malone, 1981), (Malone } \\
\text { \& Lepper, 1987), (Moreno- } \\
\text { Ger et alii, 2008), (Huang et } \\
\text { alii, 2013)2013 }\end{array}$ \\
\hline $\begin{array}{l}\text { 8.Autonomy/ } \\
\text { Control }\end{array}$ & $\begin{array}{l}\text { Games often allow players to carry out actions } \\
\text { autonomously in the process of completing game tasks. } \\
\text { Players have great control over what paths to follow in } \\
\text { order to solve the problem or perform the task. }\end{array}$ & $\begin{array}{l}\text { (Garris et alii, 2002), } \\
\text { (Malone \& Lepper, 1987), } \\
\text { (Azriel, Erthal, \& Starr, } \\
\text { 2005; Wilson et alii, 2009), } \\
\text { (Bedwell et alii, 2012), } \\
\text { (Huang et alii, 2013)2013 }\end{array}$ \\
\hline $\begin{array}{l}\text { 9.Multimedia } \\
\text { representations }\end{array}$ & $\begin{array}{l}\text { DGBL takes advantage of multimedia representations } \\
\text { to embody prior attributes like fantasy, storytelling, or } \\
\text { competition. These multimedia representations reduce } \\
\text { the cognitive demands on players' limited capacities and } \\
\text { simultaneously develop visual or spatial analysis skills. }\end{array}$ & $\begin{array}{l}\text { (Ang, Zaphiris, \& } \\
\text { Mahmooh, 2007), (de Felix } \\
\text { \& Johnson, 1993), (Hays, } \\
\text { 2005), (Huang et alii, 2013) }\end{array}$ \\
\hline 10.Feedback & $\begin{array}{l}\text { Refers to the measurement of achievement during the } \\
\text { game. Feedback provides a tool for players to learn from } \\
\text { previous actions and adjust accordingly. }\end{array}$ & $\begin{array}{l}\text { (Bedwell et alii, } \\
\text { 2012), (Azriel et alii, } \\
\text { 2005), (Wilson et alii, } \\
\text { 2009),(Calabor et alii, 2015) }\end{array}$ \\
\hline $\begin{array}{l}\text { 11. Transfer of } \\
\text { skills }\end{array}$ & $\begin{array}{l}\text { After the students have played, they should perceive that } \\
\text { what they have learned, i.e, the skills acquired, will be } \\
\text { useful for their future work. }\end{array}$ & $\begin{array}{l}\text { (Stainton, Jhonson, \& } \\
\text { Borodzicz, 2010), (Yusoff, } \\
\text { 2010), (Huang et alii, } \\
\text { 2013)2013, (Calabor et alii, } \\
\text { 2015) }\end{array}$ \\
\hline
\end{tabular}

A second dimension often considered in validating effectiveness is motivation. Motivation can be defined as'a theoretical construct used to explain the initiation, direction, intensity, persistence, and quality of behaviour' (Maehr \& Meyer, 1997 ) and it plays an important role in the satisfaction of the student (Douglas, Douglas, McClelland and Davies, 2015; Pons, Arquero and Donoso, 2012). It is multi-dimensional and is generally described (Ryan \& Deci, 2000) as being variable in both level (i.e. the intensity of motivation) and orientation (i.e. the type of motivation). When focusing on types of motivation, the literature often relies on the distinction between intrinsic and extrinsic motivation (Calabor et alii, 2015; Garris et alii, 2002; Huang et alii, 2013; Kapp, 2012). From this perspective, intrinsic motivation refers to the process where a person undertakes an activity for its own sake, for the enjoyment it provides, for the learning it permits, or for the feeling of accomplishment it evokes (Lepper, 1988). Extrinsic 
motivation, on the other hand, refers to those behaviours that are undertaken to obtain some reward or avoid punishment (Buckley \& Doyle, 2014).

If we analyse the motivational theories most widely featured in the DGBL literature, we find the ARCS (Attention, Relevance, Confidence, Satisfaction) model (Huang et alii, 2013)2013 and the Integrative Theory of Motivation, Volition, and Performance, or MVP theory (Bulander, 2010; Garris et alii, 2002), developed respectively in Keller (1987) and in Keller (2008). The ARCS model bases its development on four different variables: the first is gaining learner attention, the second is the relevance of the target material, the third is participants' confidence in their capacity to achieve the learning goals, and the fourth, finally, focuses on learner satisfaction in the worth of their effort.

Using the original ARCS model, Keller (2008) more recently proposed the MVP to include learners' volitional control, cognitive information processing, and final outcome processing (Huang et alii, 2013). This theory proposes that the learning process starts with motivational processing, which allows for the definition of goals. At this stage, the ARCS components are incorporated. The output of this first motivational process leads to the next stage, volitional processing, where learners transform their intentions regarding performance into learning actions. The third step is cognitive learning processes, where learners complete learning tasks by interacting with a multimedia learning environment. Finally, in outcome processing, learners have completed the learning task and are ready to assess the effort they have invested and compare it to their learning gain.

Based on the previous paragraphs, we have considered the ARCS model to be the most adequate at the time of analysing students' perceptions regarding motivation because is the model that better fits with the particularities of our game.

A third and also prominent dimension that has been considered in relation to the effectiveness of DGBL is that referred to the learning outcomes. An early classification is that proposed by Hoover and Whitehead (1975), who state that experiential learning occurs when a personally responsible participant cognitively, affectively, and behaviourally processes knowledge, skills, and/or attitudes in a situation of learning characterized by strong active involvement. This definition leads to a very well known classification of learning outcomes often cited in the literature: a) cognitive learning, $b$ ) behavioural learning, and $c$ ) affective learning. Faria (2001) used this classification to make sense of his classification of effective business simulation research.

Following this classification, cognitive learning might be described as the process of developing an understanding of basic concepts and underlying facts 
so that decision-making can occur (Ranchhod, Gurau, Loukis, \& Trivedi, 2014; Vos \& Brennan, 2010; Yalabik, Howard, \& Roden, 2012). Behavioural learning refers to the process whereby participants incorporate what they have learned into action and make correct decisions or change behaviours based on the content learned. Affective learning, on the other hand, refers to participants' attitudes towards what they have learned (Ranchhod et alii, 2014).

A similar classification, which has been widely used, is that in Kraiger, Ford and Salas (1993), based on Bloom's taxonomy (Bloom, Englehart, Furst, Hill, \& Krathwohl, 1956). The authors try to synthesise previous studies by proposing a classification that includes three broad categories of learning outcome: skillbased, cognitive, and affective. Skill-based outcomes can be identified with behavioural outcomes in the first classification. The DGBL literature (Bedwell et alii, 2012; Ranchhod et alii, 2014; Wilson et alii, 2009) has often built on this classification in both theoretical and empirical research. Some studies focus on specific learning outcomes or only on one of the categories, like, for example, Yalabik et alii (2012) for the cognitive outcome or Fito et alii (2014) for the skills/ behavioural outcome, while others approach the learning outcomes dimension from a multidimensional perspective (Ranchhod et alii, 2014). In our study, we define our own set of learning outcomes objectives based on the particularities of the game used and, therefore, we cannot focus on prior research as they are specific for our learning experience.

Therefore, and based on prior literature background, our study poses the following research questions:

R1: What are the perceptions of participants regarding attributes of the game?

R2: What are the perceptions of participants regarding motivation generated by the game?

R3: What are the perceptions of participants regarding learning outcomes achieved?

\section{Data and Methodology}

\subsection{Questionnaire and measurement of variables}

Previous literature identifies three main constructs as particularly important regarding the effectiveness of DGBL in an educational setting. These constructs are the attributes of the game, the motivation it engenders and the achievement of learning outcomes. Following previous literature on DGBL effectiveness (Buckley 
\& Doyle, 2014; Chen \& Law, 2015; Fitó et alii, 2014; Guillén \& Aleson 2012), the research team produced a questionnaire to measure the above-mentioned constructs. The questionnaire included four parts. The first section contained questions on the demographic variables of participants, the second addressed how students perceived the attributes of the videogame ( 24 questions), the third focused on motivation ( 34 questions) and the final section regarded perceived learning outcomes (6 questions). The questionnaire used a 5-point Likert scale ranging from 1 (Strongly disagree) to 5 (Strongly agree).

The questions on attributes were based on a previous instrument used in the literature (Huang et alii, 2013)2013. These questions were addressed to identify the participants' perceptions regarding the attributes of the videogame. In Table 2 , the final list of questions related to attributes is provided.

Table 2: Questions regarding attributes (Huang et alii, 2013)

\begin{tabular}{|l|l|}
\hline 1 & The game is challenging enough for me to play. \\
\hline 2 & The game requires me to compete. \\
\hline 3 & The game's rules are clearly presented. \\
\hline 4 & The game's rules are easy to follow. \\
\hline 5 & The game's goals are clearly presented. \\
\hline 6 & The game situates me in a fantasy world. \\
\hline 7 & The game's storyline is comprehensible. \\
\hline 8 & The game engages me deeply in the playing process. \\
\hline 9 & The game allows me to have full control of my actions. \\
\hline 10 & The game's graphics are attractive. \\
\hline 11 & The game's animations are attractive. \\
\hline 12 & The game tasks are clearly presented. \\
\hline 13 & The game provides all the information necessary for me before the playing process. \\
\hline 14 & The game provides all the information necessary for me during the playing process. \\
\hline 15 & The game's audio elements are attractive. \\
\hline 16 & The game provides explanatory feedback on my performance. \\
\hline 17 & The game provides corrective feedback on my performance. \\
\hline 18 & I can easily transfer skills I have learned from the game to the real world. \\
\hline 19 & The progression of the game task makes sense to me. \\
\hline 20 & The game provides enough support to help me accomplish the game tasks. \\
\hline 21 & The game provides enough previews to prepare me for the game playing. \\
\hline 22 & The game allows me to learn from my mistakes. \\
\hline 23 & The game keeps me interested throughout the playing process. \\
\hline 24 & The game is fun to play. \\
\hline
\end{tabular}


Regarding the motivational aspects, the researchers used the Instructional Material Motivational Survey (IMMS) derived from the ARCS model (Keller, 1987, 2008) to assess learners' perceived motivational support in Attention, Relevance, Confidence, and Satisfaction. Prior literature in DGBL (Huang et alii, 2013) has adapted the IMMS questionnaire to a DGBL environment. This research employs the ARCS model and the questions adapted from Huang et alii (2013). Table 3 shows the questions regarding motivation.

\section{Table 3: Questions regarding motivation (adapted from (Huang et alii, 2013)}

\begin{tabular}{|l|l|}
\hline 1 & When I first looked at the game, I had the impression that it would be easy for me \\
\hline 2 & The was something interesting at the beginning of the game that got my attention \\
\hline 3 & The game was more difficult to understand than I would like for it to be \\
\hline 4 & $\begin{array}{l}\text { After reading the introductory information, I felt confident that I knew what I was } \\
\text { supposed to learn from the game }\end{array}$ \\
\hline 5 & Completing the exercises in the game gave me a satisfying feeling of accomplishment \\
\hline 6 & It is clear to me how the content of the game is related to things I already know \\
\hline 7 & $\begin{array}{l}\text { The game had so much information that it was hard to pick out and remember the } \\
\text { important points }\end{array}$ \\
\hline 8 & The interface design of the game is eye-catching \\
\hline 9 & Completing activities in the game successfully was important to me \\
\hline 10 & The quality of the writing in the game helped to hold my attention \\
\hline 11 & The content of the game is so abstract that it was hard to keep my attention on it \\
\hline 12 & As I worked on the game, I was confident that I could learn the content \\
\hline 13 & I enjoyed the game so much that I would like to know more about this topic \\
\hline 14 & The design of the game looks dry and unappealing \\
\hline 15 & The content of the game is relevant to my interests \\
\hline 16 & The way the information is arranged in the game helped keep my attention \\
\hline 17 & There are explanations of examples of how people use the knowledge in the game \\
\hline 18 & The activities in the game were too difficult \\
\hline 19 & The game has things that stimulated my curiosity \\
\hline 20 & I really enjoyed learning with the game \\
\hline 21 & The amount of repetition in the game caused me to get bored sometimes \\
\hline 22 & $\begin{array}{l}\text { The content and style of writing in the game convey the impression that its content is } \\
\text { worth knowing }\end{array}$ \\
\hline 23 & I learned some things that were surprising or unexpected with the game \\
\hline 24 & $\begin{array}{l}\text { After working on the game for a while, I was confident that I would be able to pass a } \\
\text { test on the content }\end{array}$ \\
\hline 25 & The game was not relevant to my needs because I already knew most of it \\
\hline
\end{tabular}




\begin{tabular}{|l|l|}
\hline 26 & $\begin{array}{l}\text { The variety of reading passages, activities, illustrations helped keep my attention on the } \\
\text { game }\end{array}$ \\
\hline 27 & The style of writing in the game is boring \\
\hline 28 & $\begin{array}{l}\text { I could relate the content of the game to things I have seen, done or thought about in } \\
\text { my own life }\end{array}$ \\
\hline 29 & There are so many words on each game screen/page that is irritating \\
\hline 30 & It felt good to successfully complete the game \\
\hline 31 & The content in the game will be useful to me \\
\hline 32 & I could not really understand quite a bit of the material in the game \\
\hline 33 & $\begin{array}{l}\text { The good organization of the content in the game helped me be confident that I would } \\
\text { learn this material }\end{array}$ \\
\hline 34 & It was a pleasure to work on such a well-designed game \\
\hline
\end{tabular}

Learning outcomes, were again assessed based on students' own perceptions of the learning process, which is the most commonly used alternative found in previous research on the effectiveness of DGBL (Buckless, Krawczyk, \& Showalter, 2014; Huebscher \& Lendner, 2010; Tao, Cheng, \& Sun, 2009, 2012; Wynder, 2004). The researchers produced an inventory of the learning goals connecting the selected topic (working capital management) with the chosen videogame (see Table 4).

Table 4: Questions regarding learning outcomes

\begin{tabular}{|l|l|}
\hline 1 & I learned how working capital management affects cash \\
\hline 2 & $\begin{array}{l}\text { I learned how decisions related to other functional areas of the company affect working } \\
\text { capital }\end{array}$ \\
\hline 3 & I now understand better the relevance of working capital management \\
\hline 4 & I now understand better the difference between income and cashflow from operations \\
\hline 5 & I learned the main levers to manage the working capital needs of a company \\
\hline 6 & I now understand better the tensions between growth and liquidity \\
\hline
\end{tabular}

\subsection{Sample}

The sample included students enrolled in the second year of a BBA in a Spanish business school. Participants were contacted by the researchers via email, asking them to participate in the experiment. A total of 215 students registered to the experiment and were split among the different scheduled sessions. All students enrolled in the experiment had previously attended different courses on accounting and finance. Table 5 provides information about the composition of the sample by gender. The average age of the participants was 19 years. 
Table 5: Gender distribution.

\begin{tabular}{|r|l|r|r|r|}
\hline \multicolumn{2}{|c|}{} & \multicolumn{1}{|c|}{ Frequency } & Valid Percent & \multicolumn{2}{c|}{$\begin{array}{c}\text { Cumulative } \\
\text { Percent }\end{array}$} \\
\hline \multirow{3}{*}{ Valid } & Male & 113 & 52,6 & 52,6 \\
\cline { 2 - 5 } & Female & 102 & 47,4 & 100,0 \\
\cline { 2 - 5 } & Total & 215 & 100,0 & \\
\hline
\end{tabular}

All participants were asked to view the instructional video on the web platform of the videogame to understand its basic rules before starting to play. The length of the session was one hour and a half and all the participants were able to complete the game; thus, this time length was considered appropriate. Finally, they were asked to complete the questionnaire on their perceptions on attributes, motivation, and learning outcomes for the videogame. In total, 215 questionnaires were collected, all of which were considered valid.

\subsection{The videogame}

The videogame selected for this experiment was specifically designed to facilitate participants to learn financial management principles, in particular working capital management, while running a virtual company located in the inner space. The videogame used was 'Marty Raygun's Fistful of dollars', developed by ViaVivo, where the participants are challenged to make choices about customers, suppliers, and different types of inventory while running a manufacturing business. During the game, participants are exposed, to decision such as selecting among customers (suppliers) who pay (offer) high (low) prices, selecting from the customers (suppliers) who offer to pay on a cash basis (on a credit basis) or the customers that place the biggest orders. The videogame aims to develop an understanding of how to increase revenues (and profits) as quickly as possible without running out of cash. The game places the participants in the situation of understanding the implications on liquidity and profitability of many operating business decisions and grasping the relevance of a sound management of the working capital needs. Moreover, the videogame meet other criteria that the researchers found relevant:

It fits very well with the academic content of the different courses in which participants in the experiment were enrolled,

It provides a high playability, so that a very short time was required to master the basic rules of the game,

1 The videogame is freely available at $<$ http://sims.myej.org/wcgame/ $>$. 
It is, however, sufficiently complex to avoid students finding quick and easy solutions.

It can be played in one sitting, reducing in this way, the risk of high abandonment rates that have been associated with longer gaming experiences (Tao et alii, 2009).

\section{Data Analysis.}

\subsection{Attributes}

Table 6 shows the mean and standard deviation of the variables related to the assessment of the attributes of the game, ranked in a descendant order. It is worth noting that most the attributes of the game were favourably evaluated by the participants. All the mean values are above 3, and in 11 variables (out of 24), the mean value was 3.9 or higher.

The attributes that were most valued (mean above 4) were related to the fun, interest, challenge and engagement that the game engenders together with the clarity in the presentation of the rules and goals of the game. Among the less favourably valued attributes (mean bellow 3,5), participants felt that the game didn't provide enough corrective or explanatory feedback on their performance. Graphic, animations and audio elements of the game were deemed not attractive enough, driving to fail to situate the players in the fantasy world were the game takes place.

Table 6: Mean and standard deviation of the variables related to attributes.

\begin{tabular}{|l|r|r|}
\hline & Mean & $\begin{array}{c}\text { Std. } \\
\text { Deviation }\end{array}$ \\
\hline The game is fun to play & 4,40 &, 80 \\
\hline The game keeps me interested throughout the playing process & 4,31 &, 77 \\
\hline The games goals are clearly presented & 4,27 &, 88 \\
\hline The game engages me deeply in the playing process & 4,14 &, 88 \\
\hline The game is challenging enough for me to play & 4,07 &, 87 \\
\hline The game tasks are clearly presented & 4,06 &, 91 \\
\hline The games storyline is comprehensible & 4,00 &, 95 \\
\hline The games rules are clearly presented & 4,00 & 1,02 \\
\hline The game requires me to compete & 3,97 &, 85 \\
\hline The games rules are easy to follow & 3,95 &, 94 \\
\hline The progression of the game task makes sense to me & 3,95 &, 79 \\
\hline The game allows me to learn from my mistakes & 3,89 &, 970 \\
\hline
\end{tabular}




\begin{tabular}{|l|r|r|}
\hline $\begin{array}{l}\text { The game provides all the information necessary for me before the } \\
\text { playing process }\end{array}$ & 3,87 &, 98 \\
\hline $\begin{array}{l}\text { The game provides all the information necessary for me during the } \\
\text { playing process }\end{array}$ & 3,79 &, 93 \\
\hline $\begin{array}{l}\text { I can easily transfer skills I have learned from the game to the real } \\
\text { world }\end{array}$ & 3,78 \\
\hline The game allows me to full control my actions & 3,76 &, 90 \\
\hline $\begin{array}{l}\text { The game provides enough support to help me accomplish the } \\
\text { game tasks. }\end{array}$ & 3,66 \\
\hline $\begin{array}{l}\text { The game provides enough previews to prepare me for the game } \\
\text { playing }\end{array}$ & 3,64 &, 87 \\
\hline The game' s animations are attractive & 3,60 & 1,05 \\
\hline The game' s graphics are attractive & 3,50 & 1,05 \\
\hline The game situates me in a fantasy world & 3,47 & 1,17 \\
\hline The game provides explanatory feedback on my performance & 3,34 & 1,05 \\
\hline The game' s audio elements are attractive & 3,26 & 1,12 \\
\hline The game provides corrective feedback on my performance & 3,26 & 1,04 \\
\hline Mean attributes & 3.82 &, 53 \\
\hline
\end{tabular}

An independent-samples t test was conducted to evaluate whether male and female groups differ significantly in their perception of the attributes of the game. The perception of the attributes by the group «males» $(M=3,82, \mathrm{sd}=0,55)$ wasn't statistically different $(t=0,37, d f=213$, two tailed $p=0,97)$ from the perception of the group «females» $(\mathrm{M}=3,83, \mathrm{sd}=0,52)$. Table 7 and 8 summarize the descriptive statistics for both groups and the results of the t test.

Table 7: Descriptive statistics of the mean attributes by gender.

\begin{tabular}{|l|l|r|r|r|}
\hline & Gender & \multicolumn{1}{|c|}{$N$} & \multicolumn{1}{c|}{ Mean } & \multicolumn{1}{c|}{ Std. Deviation } \\
\hline \multirow{2}{*}{ Mean_attributes } & 1 & 113 & 3,82 &, 55 \\
\cline { 2 - 5 } & 2 & 102 & 3,83 &, 52 \\
\hline
\end{tabular}

Table 8: t-test for equality of means of the mean attributes by gender.

\begin{tabular}{|l|r|r|r|}
\hline & $t$ & df & \multicolumn{1}{|c|}{ Sig. (2-tailed) } \\
\hline Mean_attributes &,- 037 & 213 &, 97 \\
\hline
\end{tabular}

The study also explored whether there was a correlation between the perception of the attributes and the participant's assiduity in playing videogames beyond an academic context. The demographic section of the survey included questions regarding the liking for videogames (see table 9). A new variable «Liking videogames» was created as the addition of the scores of the variables «I 
enjoy playing digital games» and «I usually play digital games». A set of Pearson correlations were computed to determine if there were any significant correlation between the liking for videogames and the mean perception of the attributes of the videogame. The correlation between the two variables is +0.332 ; significant at the 0.01 level. Consequently, liking for videogames has a weak positive influence on the perception of the attributes of the game.

Table 9: Descriptive statistics for Liking videogames

\begin{tabular}{|l|r|r|}
\hline & Mean & Std. Deviation \\
\hline I enjoy playing digital games & 4,07 & 1,01 \\
\hline I usually play digital games & 2,78 & 1,40 \\
\hline Liking_videogames & 3,42 & 1,04 \\
\hline
\end{tabular}

Table 10: Pearson correlations between liking videogames and mean attributes.

\begin{tabular}{|l|l|r|r|}
\hline \multicolumn{2}{|c|}{} & Liking_videogames & Mean_attributes \\
\hline \multirow{2}{*}{ Liking_videogames } & Pearson Correlation & 1 &, $33^{* *}$ \\
\cline { 2 - 4 } & Sig. (2-tailed) & &, 00 \\
\hline \multirow{2}{*}{ Mean_attributes } & Pearson Correlation &, $33^{* *}$ & 1 \\
\cline { 2 - 4 } & Sig. (2-tailed) &, 00 & \\
\hline \multirow{2}{*}{$* *$ Correlation is significant at the 0.01 level (2-tailed). }
\end{tabular}

\subsection{Motivation}

As far as it concerns to motivational issues, table 11 shows the mean and standard deviation of the variables related to the assessment of the motivational support offered by the videogame during the learning process, ranked in a descendant order. The feeling of accomplishment for being able to complete the game, the enjoyment while playing it it and the perception of relevance of the contents and usefulness of the game were the most valued item (Means above 3,9). As the IMMS questionnaire includes positively-keyed and negatively-keyed items, the negatively-keyed items have been «reverse-scored» before computing individuals' total scores and before conducting any analyses. Reverse questions (and the reverse means) are shown in bold in table 11. From the reverse items, we can conclude that understanding the rationale of the game and the impression that the game was not too difficult, also helped to sustain motivation during the playing process. 
Table 11: Mean and standard deviation of the variables related to attributes.

\begin{tabular}{|c|c|c|c|}
\hline & Mean & $\begin{array}{c}\text { Std. } \\
\text { Deviation }\end{array}$ & ARCS \\
\hline I really enjoyed learning with the game & 4,18 & ,79 & Satisfaction \\
\hline It felt good to successfully complete the game & 4,17 & ,75 & Satisfaction \\
\hline $\begin{array}{l}\text { Completing activities in the game successfully was important } \\
\text { to me }\end{array}$ & 4,06 & ,84 & Satisfaction \\
\hline $\begin{array}{l}\text { It is clear to me how the content of the game is related to things } \\
\text { I already know }\end{array}$ & 4,04 &, 80 & Relevance \\
\hline $\begin{array}{l}\text { Completing the exercises in the game gave me a satisfying feeling } \\
\text { of accomplishment }\end{array}$ & 3,99 & 85 & Satisfaction \\
\hline The content in the game will be useful to me & 3,95 & ,76 & Relevance \\
\hline The game has things that stimulated my curiosity & 3,93 & ,83 & Attention \\
\hline It was a pleasure to work on such a well designed game & 3,85 & ,83 & Satisfaction \\
\hline The content of the game is relevant to my interests & 3,83 & ,85 & Relevance \\
\hline $\begin{array}{l}\text { I enjoyed the game so much that I would like to know more } \\
\text { about this topic }\end{array}$ & 3,83 &, 87 & Relevance \\
\hline $\begin{array}{l}\text { As I worked on the game I was confident that I could learn the } \\
\text { concept }\end{array}$ & 3,83 &, 88 & Confidence \\
\hline $\begin{array}{l}\text { There was something interesting at the beginning of the game } \\
\text { that got my attention }\end{array}$ & 3,77 & ,94 & Attention \\
\hline $\begin{array}{l}\text { When I first looked at the game I had the impression that it } \\
\text { would be easy for me }\end{array}$ & 3,73 & ,96 & Attention \\
\hline $\begin{array}{l}\text { The way the information is arranged in the game helped keep my } \\
\text { attention on it }\end{array}$ & 3,67 &, 83 & Attention \\
\hline $\begin{array}{l}\text { The variety of reading passages, activities, illustrations... helped } \\
\text { keep my attention on the game }\end{array}$ & 3,65 & ,97 & Attention \\
\hline $\begin{array}{l}\text { After reading the introductory information, I felt confident that } \\
\text { I knew what I was supposed to learn from the game }\end{array}$ & 3,65 & ,91 & Confidence \\
\hline The interface design of the game is eye-catching & 3,65 & ,92 & Attention \\
\hline $\begin{array}{l}\text { The good organization of the content in the game helped me be } \\
\text { confident that I would learn this material }\end{array}$ & 3,65 & 86 & Confidence \\
\hline $\begin{array}{l}\text { I could relate the content of the game to things I have seen, done } \\
\text { or thought about in my own life }\end{array}$ & 3,61 & 87 & Relevance \\
\hline $\begin{array}{l}\text { I learned some things that were surprising or unexpected with } \\
\text { the game }\end{array}$ & 3,54 & 84 & Attention \\
\hline $\begin{array}{l}\text { The content and style of writing in the game convey the } \\
\text { impression that its content is worth knowing }\end{array}$ & 3,51 & 80 & Relevance \\
\hline $\begin{array}{l}\text { After working on the game for a while, I was confident that I } \\
\text { would be able to pass a test on the content }\end{array}$ & 3,51 & 97 & Confidence \\
\hline $\begin{array}{l}\text { The quality of the writing in the game helped to hold my } \\
\text { attention }\end{array}$ & 3,50 & ,96 & Attention \\
\hline $\begin{array}{l}\text { There are explanations of examples of how people use the } \\
\text { knowledge in the game }\end{array}$ & 3,14 & 1,01 & Confidence \\
\hline
\end{tabular}




\begin{tabular}{|c|c|c|c|}
\hline & Mean & $\begin{array}{c}\text { Std. } \\
\text { Deviation }\end{array}$ & ARCS \\
\hline $\begin{array}{l}\text { The game was more difficult to understand than I would like } \\
\text { for it to be }\end{array}$ & $2,87(3,13)$ & 1,11 & Relevance \\
\hline $\begin{array}{l}\text { The game had so much information that it was hard to pick } \\
\text { out and remember the important points }\end{array}$ & $2,75(3,25)$ & 1,09 & Confidence \\
\hline $\begin{array}{l}\text { I could not really understand quite a bit of the material in the } \\
\text { game }\end{array}$ & $2,57(3.43)$ & 1,12 & Satisfaction \\
\hline $\begin{array}{l}\text { The game was not relevant to my needs because I already knew } \\
\text { most of it }\end{array}$ & $2,55(3,45)$ & 1,08 & Relevance \\
\hline $\begin{array}{l}\text { The amount of repetition in the game caused me to get bored } \\
\text { sometimes }\end{array}$ & $2,54(3,46)$ & 1,07 & Attention \\
\hline The design of the game looks dry and unappealing & $2,49(3,51)$ & 1,15 & Attention \\
\hline The style of writing in the game is boring & $2,47(3.53)$ & 1,02 & Satisfaction \\
\hline $\begin{array}{l}\text { The content of the game is so abstract that it was hard to keep } \\
\text { my attention on it }\end{array}$ & $2,44(3.56)$ & 1,18 & Attention \\
\hline The activities in the game were too difficult & $2,39(3.61)$ & 1,02 & Confidence \\
\hline $\begin{array}{l}\text { There are so many words on each game screen/page that is } \\
\text { irritating }\end{array}$ & $2,38(3.62)$ & 1,14 & Satisfaction \\
\hline Mean motivation & 3,67 & 0,45 & \\
\hline
\end{tabular}

After reverting the inverse questions, the mean for the perceived motivational support was calculated (3.67, standard deviation $=0,45)$. We also wanted to contrast the difference in the perceived motivational support by gender, so separated means were calculated for every group (table 12) and an independentsamples $t$ test was performed to assess if male and female differ significantly or not in their perception of the motivational support provided by the game. Although the mean motivation perceived by females was slightly higher than the perceived by male (table 12), the difference was not statistically significant $(t=1,56, d f=213$, two tailed $\mathrm{p}=0,12$, table 13$)$.

Table 12: Descriptive statistics of mean motivation by gender.

\begin{tabular}{|l|l|r|r|r|}
\hline & Gender & \multicolumn{1}{|c|}{$N$} & \multicolumn{1}{c|}{ Mean } & \multicolumn{1}{c|}{ Std. Deviation } \\
\hline \multirow{2}{*}{ Mean_Motivation } & 1 & 113 & 3,62 &, 44 \\
\cline { 2 - 5 } & 2 & 102 & 3,72 &, 45 \\
\hline
\end{tabular}

Table 13 : $t$-test for equality of means of mean motivation by gender.

\begin{tabular}{|l|r|r|r|}
\hline & $t$ & $d f$ & \multicolumn{1}{|c|}{ Sig. (2-tailed) } \\
\hline Mean_Motivation & $-1,56$ & 213 &, 12 \\
\hline
\end{tabular}


Finally, the correlation between the liking for videogames and motivation that the videogame engendered was considered. Results of the Pearson correlation coefficient between these two variables are shown in table 14, where we can see a positive but, again, very weak correlation.

Table 14: Pearson correlations between liking videogames and mean motivation.

\begin{tabular}{|l|l|r|r|}
\hline \multicolumn{2}{|c|}{} & Liking_videogames & Mean_Motivation \\
\hline \multirow{2}{*}{ Liking_videogames } & Pearson Correlation & 1 &, $25^{* *}$ \\
\cline { 2 - 4 } & Sig. (2-tailed) & &, 00 \\
\hline \multirow{2}{*}{ Mean_Motivation } & Pearson Correlation &, 00 & 1 \\
\cline { 2 - 4 } & Sig. (2-tailed) & \multicolumn{2}{|c|}{} \\
\hline \multirow{2}{*}{${ }^{* *}$. Correlation is significant at the 0.01 level (2-tailed). } \\
\hline
\end{tabular}

\subsection{Learning outcomes}

When it comes to perceived achievement of learning outcomes, the outcome is clearly favorable (all the items in the questionnaire show a mean above 3.9). That yields an average mean for learning outcomes of 4.00 and a standard deviation of 0,678 .

Table 15: Mean and standard deviation of the variables related to learning outcomes.

\begin{tabular}{|l|r|r|}
\hline & Mean & \multicolumn{1}{|c|}{$\begin{array}{c}\text { Std. } \\
\text { Deviation }\end{array}$} \\
\hline I learned how working capital management affects cash & 4,07 &, 81 \\
\hline $\begin{array}{l}\text { I learned how decisions related to other functional areas of the } \\
\text { company affect working capital }\end{array}$ & 4,05 &, 83 \\
\hline I now understand better the relevance of working capital management & 4,04 &, 81 \\
\hline $\begin{array}{l}\text { I now understand better the difference between income and cash flow } \\
\text { from operations }\end{array}$ & 3,98 &, 84 \\
\hline $\begin{array}{l}\text { I learned the main levers to manage the working capital needs of a } \\
\text { company }\end{array}$ & 3,96 &, 83 \\
\hline I now understand better the tensions between growth and liquidity & 3,98 & 4,00 \\
\hline Mean Learning Outcomes &, 67 \\
\hline
\end{tabular}

The mean learning outcomes shown in table 15, was broken down into separated means for males $(4,01)$ and females $(3,98)$. These group means were not significantly different $(t=0,34, d f=213$, two tailed $p=0,72)$. Finally, the 
perceived achievement of learning outcomes after playing the game shows a weak positive correlation (Pearson's correlation $=0,26$, significant at the 0.01 level, 2 -tailed) with the liking for videogames (see tables 16,17 and 18 respectively).

Table 16: Descriptive statistics of learning outcomes by gender.

\begin{tabular}{|l|l|r|r|r|}
\hline & Gender & N & \multicolumn{1}{c|}{ Mean } & \multicolumn{1}{c|}{ Std. Deviation } \\
\hline \multirow{2}{*}{ Mean2_learningoutcomes } & 1 & 113 & 4,01 &, 65 \\
\cline { 2 - 5 } & 2 & 102 & 3,98 &, 70 \\
\hline
\end{tabular}

Table 17: t-test for equality of means of earning outcomes by gender.

\begin{tabular}{|l|l|l|l|}
\hline & $t$ & $d f$ & Sig. (2-tailed) \\
\hline Mean2_learningoutcomes &, 34 & 213 &, 72 \\
\hline
\end{tabular}

Table 18: Pearson correlations between liking videogames and learning outcome.

\begin{tabular}{|l|l|r|r|}
\hline \multicolumn{2}{|c|}{} & $\begin{array}{c}\text { Liking_ } \\
\text { videogames }\end{array}$ & $\begin{array}{c}\text { Mean2_ } \\
\text { learningoutcomes }\end{array}$ \\
\hline \multirow{2}{*}{ Liking_videogames } & Pearson Correlation & 1 &, $26^{* *}$ \\
\cline { 2 - 4 } & Sig.(2-tailed) & &, $26^{* *}$ \\
\hline \multirow{3}{*}{ Mean2_learningoutcomes } & Pearson Correlation &, 00 & 1 \\
\cline { 2 - 4 } & Sig. (2-tailed) & & \\
\hline \multirow{2}{*}{${ }^{* *}$. Correlation is significant at the 0.01 level (2-tailed). }
\end{tabular}

\subsection{Liking for videogames}

An independent-samples t test was conducted to evaluate whether male and female groups differ significantly in liking for videogames beyond an educational context. The perception of the attributes by the group «males» $(M=3,78$, $\mathrm{sd}=1,01)$ was statistically different $(t=5.64, \mathrm{df}=213$, two tailed $\mathrm{p}=0,00)$ from the perception of the group «females» $(M=3,02, s d=, 93)$. Table 19 and 20 summarize the descriptive statistics for both groups and the results of the test.

Table 19: Descriptive statistics of liking videogames by gender.

\begin{tabular}{|l|l|r|r|r|}
\hline & Gender & \multicolumn{1}{|c|}{$N$} & Mean & Std. Deviation \\
\hline \multirow{2}{*}{ Liking_videogames } & 1 & 113 & 3,78 & 1,01 \\
\cline { 2 - 5 } & 2 & 102 & 3,02 &, 93 \\
\hline
\end{tabular}


Table 20: $\mathrm{t}$-test for equality of means of mean motivation by gender.

\begin{tabular}{|l|r|r|r|}
\hline & \multicolumn{1}{|c|}{$T$} & \multicolumn{1}{|c|}{ df } & Sig. (2-tailed) \\
\hline Liking_videogames & 5,64 & 213 &, 000 \\
\hline
\end{tabular}

As the fondness for videogames was significantly different between the two groups, partial correlations between liking for videogames and attributes, motivation and learning outcomes were computed controlling for gender. The correlation coefficients obtained were 0,$35 ; 0,31$ and 0,27 respectively, significant at the 0.01 level, 2-tailed (tables 21, 22 and 23, respectively). This confirms that gender has a weak correlation with the perception by the students of the constructs that determine the effectiveness of DGBL. However, as the correlation coefficients controlling for gender are higher than the original significant zero order correlation $(0,33 ; 0,25$ and 0,26 respectively) this indicates that the latter were underestimated by the effect of gender, which somewhat impacts slightly on the three constructs.

Table 21: Pearson correlations between liking videogames and attributes, controlling by gender.

\begin{tabular}{|l|l|l|l|l|}
\hline \multicolumn{2}{|l|}{ Control Variables } & $\begin{array}{l}\text { Mean_ } \\
\text { attributes }\end{array}$ & $\begin{array}{l}\text { Liking_ } \\
\text { videogames }\end{array}$ \\
\hline \multirow{3}{*}{ Gender } & \multirow{3}{*}{ Mean_attributes } & Correlation & 1,00 &, 35 \\
\cline { 3 - 5 } & \multirow{2}{*}{ Liking_videogames } & Significance (2-tailed) &. &, 00 \\
\cline { 3 - 5 } & Correlation &, 35 & 1,00 \\
\cline { 3 - 5 } & Significance (2-tailed) &, 00 &. \\
\hline
\end{tabular}

Table 22: Pearson correlations between liking videogames and motivation, controlling by gender.

\begin{tabular}{|c|c|c|c|c|}
\hline \multicolumn{3}{|c|}{ Control Variables } & \multirow{2}{*}{ 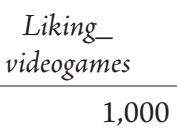 } & \multirow{2}{*}{$\begin{array}{r}\frac{\begin{array}{c}\text { Mean_ } \\
\text { Motivation }\end{array}}{, 314}\end{array}$} \\
\hline \multirow{4}{*}{ Gender } & \multirow[b]{2}{*}{ Liking_videogames } & Correlation & & \\
\hline & & $\begin{array}{l}\text { Significance } \\
\text { (2-tailed) }\end{array}$ & & ,000 \\
\hline & \multirow[b]{2}{*}{ Mean_Motivation } & Correlation & ,314 & 1,000 \\
\hline & & $\begin{array}{l}\text { Significance } \\
\text { (2-tailed) }\end{array}$ & ,000 & \\
\hline
\end{tabular}


Table 23: Pearson correlations between liking videogames and learning outcomes, controlling by gender.

\begin{tabular}{|l|l|l|r|r|}
\hline \multicolumn{2}{|l|}{ Control Variables } & \multicolumn{1}{c|}{$\begin{array}{c}\text { Liking_ } \\
\text { videogames }\end{array}$} & $\begin{array}{c}\text { Mean2_ } \\
\text { learning } \\
\text { outcomes }\end{array}$ \\
\hline \multirow{3}{*}{ Gender } & \multirow{3}{*}{ Liking_videogames } & Correlation & 1,00 &, 27 \\
\cline { 2 - 5 } & $\begin{array}{l}\text { Significance } \\
(2 \text {-tailed) }\end{array}$ &, 27 &, 00 \\
\cline { 2 - 5 } & $\begin{array}{l}\text { Mean2_ } \\
\text { learningoutcomes }\end{array}$ & $\begin{array}{l}\text { Correlation } \\
\text { Significance } \\
\text { (2-tailed) }\end{array}$ &, 00 & \\
\hline
\end{tabular}

\section{Discussion and conclusions}

The present study was designed to assess the effectiveness of videogames as a new learning tool in a higher education setting. To this end, attributes, motivation, and learning outcomes - as three of the main dimensions that play a role in the effectiveness of DGBL - have been considered in an experiment with BBA students in a Spanish Business School. The following paragraphs discuss the findings of the study and highlight some implication for educators.

Previous literature on DGBL has discussed its importance of generating an engaging experience, as it enables players to immerse themselves in the game. Participants in the experiment reported that the attributes of the videogame engaged them deeply, that the game was fun to play and that it generated a very challenging and rewarding playing experience. Consequently, the game kept them interested throughout the playing process. Among the most valued attributes by students, this research also has identified the provision of clear information about the goals and rules of the game. On the other extreme, the weakest attributes identified by the participants were related to the feedback provided by the game. These findings suggest that briefing and debriefing activities are crucial for a successful implementation of DGBL. Briefing and debriefing activities can be seen as levers the instructors can use to enhance the connection of the gaming activity to the intended learning outcomes. If insufficient indications are provided, students may not appreciate what they are expected to do and what is the rationale of the game, and consequently, may not be appropriately engaged. Aiming at such purpose, activities such as presenting the game objectives, assignments on individual/group performance, group discussions, interaction between the instructor and the players to provoke critical thinking or presentations help to accomplish the learning outcomes and enhance the students' learning experience. 
No significant difference was found between gender and the perception of the attributes.

Turning now to the experimental evidence regarding motivation, the results of this study also confirm that the videogame produced high levels of motivational support in all the dimensions considered in the ARCS model (Keller, 1987, 2008). The game was able to catch and sustain the attention of the participants during the game play, and seemed attainable in terms of its difficulty. Likewise, the topics developed in the videogames were also identified as relevant by the students, conveying the impression that it was an important topic that it was worth knowing. This greater readiness to learn more is likely to be related to the high level of satisfaction perceived during the playing process. As far as confidence is concerned, understanding the game and the reliance of being able to successfully complete it, provided an important support to sustain the motivation of the participants. Finally, students expressed a very high level of satisfaction with the experience and a strong feeling of accomplishment. No difference was found between gender and perception of motivational support.

Finally, the results of this experiment confirm that the videogame generated in the participants a favorable perception regarding the achievement of learning outcomes (Mean 4,00 on a 5 points Likert scale). Again, perception by gender wasn't significantly different.

Contrary to expectations, a very weak correlation was found between liking for videogames and the perception of attributes, motivational support and achievement of learning outcomes. The authors consider this finding especially relevant, because, disregarding the fondness for videogames of the students, the use of videogames was able to provide an important motivational support during the learning process and has generated a very favorable perception regarding the attributes of the game and the achievement of the expected learning outcomes. Consequently, this study suggests that even those students that declare a low esteem for videogames (or do not play it regularly) can benefit of its use in a learning environment. A note of caution is due here, even though the liking for videogames beyond the academic activities showed than the male group fondness was significantly higher than in the female group, both groups report a very positive evaluation of the gaming activity. From all the above, this study supports the inclusion of videogames as a learning tool in environments where additional motivation is required.

This finding was somehow unexpected, and suggests that more research on this topic needs to be undertaken. Further work could also investigate if participants with different seniority respond similarly to videogames. It may be 
the case that elder participants (the average age of the sample was 19 years), with less computer literacy, could produce different results.

The main practical implication of this research is that business educators considering the introduction of videogames in their courses may find, in this study, guidance about the expectable outcomes of using it. The results presented in this study support the inclusion of videogames as a complement to other methodologies in higher education accounting business environments. From the experience of the authors, undergraduate accounting students often struggle to catch the difference between liquidity and profits, and between the cash flow statement and the income statement. The videogame places them in a situation where they have to manage the cash conversion cycle of the company. Consequently, by playing the videogame, students integrate the effects on the cash position and the profits of the company of the business decisions they make, driving to a better understanding of the relation (and difference) between the cash flow statement and the income statement. The game also permits to teach the students some basic accounting concepts and terminology. This goes together with a better understanding of some basic principles of financial management and to an enhanced comprehension of the interdependence between various business functions. This findings are consistent with other previous studies that have confirmed the effectiveness of digital game base learning in the achievement of cognitive learning outcomes (Ranchhod, Gurau, Loukis, \& Trivedi, 2014; Vos \& Brennan, 2010; Yalabik, Howard, \& Roden, 2012).

Notwithstanding this contribution, this study is not free of limitations. A first limitation is that the experience presented in this article was relatively short (one hour and a half). Undoubtedly, this short span of time helped to sustain the engagement and motivation, could be the case that longer gaming experiences could not generate the same level of satisfaction. Furthermore, this session was designed to be in a face-to-face teaching context, with the presence of an instructor. It can be reasonably assumed that it will be easier for students to get started in such face-to-face context, than if working in a purely online context. In the latter situation they won't be able to ask for help from the instructor or from other students if they have difficulties, for instance, understanding what they are mean to do with the game. Students finding this type of problems may lose interest and become demotivated. Therefore, and regarding the implementation of DGBL, it seems that ensuring support for students at the start of the games and during its development is of paramount importance to achieve the expected outcomes of DGBL. 


\section{Bibliography}

Amory, A. (2007). "Game object model versión II: A theoretical model for educational game development». Educational Technology Reserach and Development, 55, 55-77.

Ang, C. S.; Zaphiris, P., \& Maнmooh, S. (2007). «A model of cognitive loads in massively online role playing games». Interacting with Computers, 19, 167 179.

Azriel, J. A.; Erthal, M. J., \& Starr, E. (2005). «Answers, Questions, and Deceptions: What Is the Role of Games in Business Education?» Journal of Education for Business, 81(1), 9-13.

Bedwell, W; Pavlas, D; Heyne, K.; Lazzara, E., \& Salas, E. (2012). «Toward a Taxonomy Linking Game Attributes to Learning: An Empirical Study». Simulation E Gaming, 43(6), 729-760.

Bloom, B. S.; Englehart, N. D.; Furst, E. J; Hill, W. H., \& Krathwohl, D. R. (1956). Taxonomy of Educational Objectives: The classification of educational goals. Handbook I: Cognitive Domain. New York: David Mc Kay.

Buckless, F. A.; Krawczyk, K., \& Showalter, D. S. (2014). «Using Virtual Worlds to Simulate Real-World Audit Procedures». Issues in Accounting Education, 29(3), 389-417.

Buckley, P., \& Doyle, E. (2014). «Gamification and student motivation». Interactive Learning Environments, ahead of print, 1-14.

Bulander, R. (2010). «A conceptual framework of serious games for higher education-Conceptual Framework of the Game INNOV8 to Train Students in Business Process Modelling». Paper presented at the ICE-B 2010: Proceedings of the International Conference on e-Business, Athens, Greece.

Calabor, M.; Mora, A., \& Moya, S. (2015). «Learning accounting through serious games: attributes and motivatioin». Paper presented at the 38 th European Accounting Association Annual Congress, Glasgow (UK).

Calabor, M. S.; Mora, A., \& Moya, S. (2017). «Adquisición de competencias a través de juegos serios en el área contable: un análisis empírico». Revista de Contabilidad, available on line. http $\$ / / \mathrm{dx}$.doi.org/10.1016/j. rcsar.2016.11.001

Calabor, M. S.; Moya, S., \& Mora, A. (2016). «The future of SeriousGames in Higher Education: Delphy Study on the educator's visión». Paper presented at the XXXIX European Accounting Association Conference, Maastricht.

Carenys, J., \& Moya, S. (2016). «Digital game-based learning in accounting and business education». Accounting Education, 25(6), 598-651. 
Carenys, J.; Moya, S., \& Perramon, J. (2016). «Is it worth it toconsider videogames in accounting education? A comparison of a simulation and a videogame in attributes, motivation and learning outcomes». Revista de Contabilidad, available on line. http://dx.doi.org/10.1016/j. rcsar.2016.07.003

Chen, C., \& Law, V. (2015). «Scaffolding individual and collaborative gamebased learning in learning performance and intrinsic motivation». Computers in Human Behavior, ahead of print.

Csikszentminalyi, M. (1975). «Play and intrinsic rewards». Journal of Humanistic Psychology, 15(3), 41-63.

De Felix, J., \& Johnson, R. (1993). «Learning from video games». Computers in the Schools, 9, 119-134.

Dickey, M. D. (2007). «Game design and learningः A conjectural analysis of how massive multiple online role-playing games (MMORPGs) Foster intrinsic motivation». Educational Technology Reserach and Development, 55, 253-273.

Douglas, J*; Douglas, A.; McClelland, R*, \& Davies, J. (2015). «Understanding studentsatisfaction and dissatisfaction: An interpretive study in the UK higher educationcontext». Studies in Higher Education, 40, 329-349.

FARIA, A. J. (2001). "The changing nature of business simulation/gaming research: a brief history». Simulation and Gaming, 32(1), 97-110.

Fitó, A.; Hernández, A., \& Serradell, E. (2014). «Comparing student competences in face-to-face and online business game». Computers in Human Behavior, 30, 452-459.

Fitó, A.; Hernández, A., \& Serradell, E. (2015). «The effects of competences on learning results: An educational experience with a business simulator». Computers in Human Behavior, 51, 910-914.

Garris, R.; Ahlers, R., \& Driskell, J. (2002). «Games, Motivation, and Learning: A Research and Practice Model». Simulation E Gaming, 33, 441467.

Guillén, V., \& Aleson, M. (2012). «Serious games and learning effectiveness: The case of" It's a Deal!"». Computers E Education, 58(1), 435-448.

Hays, R. (2005). The Effectiveness of Instructional Games: A Literature Review and Discussion. Naval Air Warfare Center Training Systems Division. Orlando (Florida).

Hoover, D., \& Whitehead, C. (1975). «An experiential-cognitive methodology in the first course in management: some preliminary results». Simulation Games and Experiential Learning in Action, 2, 23-25. 
Huang, W. D.; Johnson, T. E., \& Han, S.-H. C. (2013). «Impact of online instructional game features on college students' perceived motivational support and cognitive investment: A structural equation modeling study». Internet and Higher Education, 17, 58-68.

Huebscher, J., \& Lendner, C. (2010). «Effects of Entrepreneurship Simulation Game Seminars on Entrepreneurs' and Students' Learning». Journal of Small Business and Entrepreneurship, 23(4), 543-554,649.

KAPP, K. M. (2012). The gamification of learning and instruction, game-based methods, and strategies for training and education. USA: John Wiley \& Sons.

Keller, J. (1987). «Development and use of the ARCS model of instructional design». Journal of Instructional Development, 10(3), 2-10.

Keller, J. (2008). "An integrative theory of motivation, volition and performance». Technology, Instruction, Cognition and Learning, 6, 79-104.

Kraiger, K.; Ford, J. K., \& Salas, E. (1993). «Application of cognitive, skillbased, and affective theories of learning outcomes to new methods of training evaluation». Journal of Applied Psychology, 78, 311-328.

LePper, M. R. (1988). «Motivational considerations in the study of instruction». Cognition and Instruction, 5(4), 289-309.

Maehr, M. L., \& Meyer, H. A. (1997). "Understanding motivation and schooling: where we've been, where we are and where we need to go». Educational Psychology Review, 9(4), 371-409.

Malone, T. (1981). «Toward a theory of intrinsically motivating instruction». Cognitive Science, 4, 333-369.

Malone, T., \& Lepper, M. (1987). «Making learning fun: A taxonomy of intrinsec motivations for learning». Aptitude, learning and instruction, 3 (1987), 223-253.

Moreno-Ger, P;; Burgos, D.; Sierra, J. L., \& Fernández-Manjón, B. (2008). «Educational game design for online education». Computers in Human Behavior, 24, 2530-2540.

Pons, D.; Arquero, J. L., \& Donoso, J. A. (2012). «Distance learning and academicperformance in accounting: A comparative study of the effect of the use ofvideoconferencing». Revista de Contabilidad, 15(2), 195-209.

Ranchhod, A.; Gurau, C.; Loukis, E., \& Trivedi, R. (2014). «Evaluating the educational effectiveness of simulation games: A value generation model». Information Sciences, 264, 75-90.

Rieber, L., \& NoAh, D. (2008). «Games, simulations and visual metaphors in education: Antagonism between enjoyment and learning». Educational Media International, 45, 77-79. 
Rieber, L. P., \& Matzko, M. J. (2001). «Serious design of serious play in physics». Educational Technology Research and Development, 41(1), 14-24.

Ryan, R. M., \& Deci, E. L. (2000). «Intrinsic and extrinsic motivations: classic definitions and new directions». Contemporary Educational Psychology, 25(1), 54-67.

Stainton, A.; Jhonson, J., \& Borodzicz, E. (2010). «Educatonal Validity of Business Gaming Simulation: A Research Methodology Framework». Simulation E Gaming, 4(5), 705-723.

TAo, Y.-H.; Cheng, C.-J., \& Sun, S.-Y.(2009). «What influences college students to continue using business simulation games? The Taiwan experience». Computers E Education, 53(3), 929-939.

Tao, Y.-H.; Cheng, C.-J., \& Sun, S.-Y. (2012). «Alignment of Teacher and Student Perceptions on the Continued use of Business Simulation Games». Educational Technology \& Society, 15(3), 177-189.

Vos, L., \& Brennan, R. (2010). «Marketing simulation games: student and lecturer perspectives». Marketing Intelligence E Planning, 28(7), 882-897.

Westera, W*; Nadolski, R. J.; Hummel, H. G. K., \& Wopereis, I. G. J. H. (2008). «Serious games for higher education: a framework for reducing design complexity». Journal of Computer Assisted Learning, 24(5), 420-432.

Wilson, K.; Bedwell, W.; Lazzara, E.; Salas, E.; Burke, C.; Estock, J; Conkey, C. (2009). «Relationships Between Game Attributes and Learning Outcomes». Simulation E Gaming, 40(2), 217-266.

Wynder, M. (2004). «Facilitating creativity in management accounting: a computerized business simulation». Accounting Education, 13(2), 231-250.

Yalabik, B.; Howard, M., \& Roden, S. (2012). «The innovation gameः lessons in strategy and managing operations». International Journal of Operations $\mathcal{E}$ Production Management, 32(12), 1441-1459.

Yusoff, A. (2010). A Conceptual Framework for Serious Games and its Validation. Unpublised doctoral dissertation. University of Southampton, Southhampton. 